\title{
BIRDS STRIKE - IMPACT ON THE SAFETY OF CIVIL AIRCRAFT OPERATIONS IN POLAND IN 2008-2018
}

\author{
Włodzimierz BALICKI*, Paweł GLOWACKI ${ }^{*}$, Leszek LOROCH \\ * kukasiewicz Research Network - Institute of Aviation, Poland, 02-256 Warsaw, al. Krakowska 110/114, Poland \\ Wlodzimierz.Balicki@ilot.lukasiewicz.gov.pl, Pawel.Glowacki@ilot.lukasiewicz.gov.pl, Leszek.Loroch@ilot.lukasiewicz.gov.pl
}

received 1 May 2020, revised 8 June 2021, accepted 14 June 2021

\begin{abstract}
The authors assessed the real threat to civil aircraft traffic in Poland resulting from bird strikes. It was found that in the period 2013-2018, the probability of such events increased by four times. Data for this work were downloaded from the ECCAIRS database maintained by the Civil Aviation Authority. Air traffic events have been collected for several years in this database. An assessment of the energy of bird collision with the aircraft, resulting from the bird's mass and relative speed of movement, was also presented. Ways to minimise the risk of collision were described by introducing crew warning systems and means to scare off birds from the airport grounds. The method of testing the resistance of turbine engines to the foreign body's absorption was also shown, as well as design methods for increasing the engine resistance to bird strikes.
\end{abstract}

Key words: air transport, air traffic safety, aviation events, bird strike

\section{INTRODUCTION}

Birds and planes move in the same environment; this is the reason for the most frequent incidents occurring near airports. The first recorded bird collision report is from Orville Wright. His plane collided with a blackbird in Dayton in 1905. The first recorded casualty was that of pilot Calbraith Rogers, whose plane drowned in the sea after the collision with a seagull (3 April 1912 on Long Beach - California). The most tragic bird strike accident so far, claiming the lives of 62 passengers, was that of the Lockheed Electra L-188 plane, which crashed during take-off from Boston airport when three engines (Allison 501D) failed after a collision with a herd of starlings. The most famous case of a bird strike involved US Airways Flight 1549 in 2009 (popularly known as the 'Miracle on the Hudson'). Six minutes after take-off, the aircraft (Airbus A320-214) lost power in both engines as a result of a collision with a flock of wild geese, which caused damage to its engines and forced the pilot to perform an emergency landing on the Hudson River. Thanks to the pilot's skills, all the passengers survived the disaster (Fortońska, 2018, Korte, 2019).

The increase in the number of air operations in the world, the change in bird migration habits, and faster and quieter turbinepowered aircraft, which give birds less time to get off the flight line of an aircraft, are some of the causes for the increase observed in the number of collisions. The Federal Aviation Administration (FAA) in its study (1990-1999) reported that, while the number of reported bird collisions has increased rapidly, the number of reported harmful ones has decreased since 2000. The number of reported collisions occurring in US airspace has increased by $144 \%$ from 5,872 in 2000 to 14,349 in 2017 . The number of serious incidents, however, fell by $16 \%$, from 741 to 625 . This decrease was most evident for commercial aircraft in the airport environment (at $<1,500 \mathrm{ft}$ above ground level). On average, there are 8-19 collisions per 10,000 flights, depending on the world region. The number of these cases depends on the season: in the northern hemisphere, the highest number of incidents occurs in August, September and October ( $40 \%$ of the annual number). The reason is migration of birds. The probability of a collision is significantly influenced by the flight altitude: as much as $80 \%$ is for flights below 1,000 feet (take-off, approach, moving flight). However, similar events have not decreased in the case of general aviation (GA) aircraft (Directive 2003/42/EC). These phenomena have attracted the interest of insurance companies, which pay significant compensation to the heirs of crash victims, as well as to airlines bearing the costs of aircraft maintenance and decommissioning. The average cost of removing the effects of a collision between a passenger aircraft and birds is US $\$ 235,000$ if damage is detected and US $\$ 22,000$ if there is no damage (inspection costs, cancelled flight, etc.). The seriousness of these issues led the International Civil Aviation Organization (ICAO) to establish the Bird Strike Committee Europe (Matijaca, 2001, 2008).

In Poland, there is also a significant increase in the number of air events caused by collisions with birds; however, no serious effects resulting from them were observed.

\subsection{Methodology of analysis}

The number of aircraft registered in Poland is growing (cf. Tab. 1 and Fig. 1). Some regularity is maintained as follows: there are 10 light aircraft with maximum take-off mass (MTOM) $<5,700 \mathrm{~kg}$, while for one large aircraft it is MTOM $>$ $5,700 \mathrm{~kg}$.

The number of events caused by birds was referred to the number of aircraft registered in a given year to objectify the results of comparisons (Balicki W. et al 2016). Coefficient has been 
added as:

$\mathrm{K}_{1000}=\frac{1000 * \mathrm{~N}_{\mathrm{ev}}}{\mathrm{N}_{\mathrm{reg}}}$

where: $\mathrm{Nev}_{\mathrm{ev}}$ is the number of events involving birds and $\mathrm{N}_{\text {reg }}$ is the number of aircraft registered in the year under consideration.

Tab. 1. Change in the number of aircraft registered in Poland

\begin{tabular}{|c|c|c|c|c|c|c|c|c|c|}
\hline Year & స్రి & 옹 & 음 & ָั & ్ㅗ & 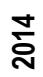 & $\stackrel{\circ}{\circ}$ & 충 & ㅎ․ \\
\hline $\begin{array}{l}\text { Light } \\
\text { air- } \\
\text { craft }\end{array}$ & 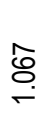 & 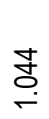 & ণ্ণ & 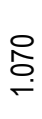 & $\stackrel{\mathscr{O}}{\circ}$ & $\stackrel{ }{\circ}$ & $\stackrel{⿱}{\stackrel{丶}{厂}}$ & 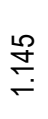 & $\stackrel{\infty}{\stackrel{0}{\circ}}$ \\
\hline $\begin{array}{l}\text { Large } \\
\text { air- } \\
\text { craft }\end{array}$ & চ & 8 & ం & $\stackrel{\mathscr{N}}{\simeq}$ & $\stackrel{m}{\square}$ & $\stackrel{0}{=}$ & $\stackrel{\simeq}{\simeq}$ & $\dddot{m}$ & กิ \\
\hline
\end{tabular}
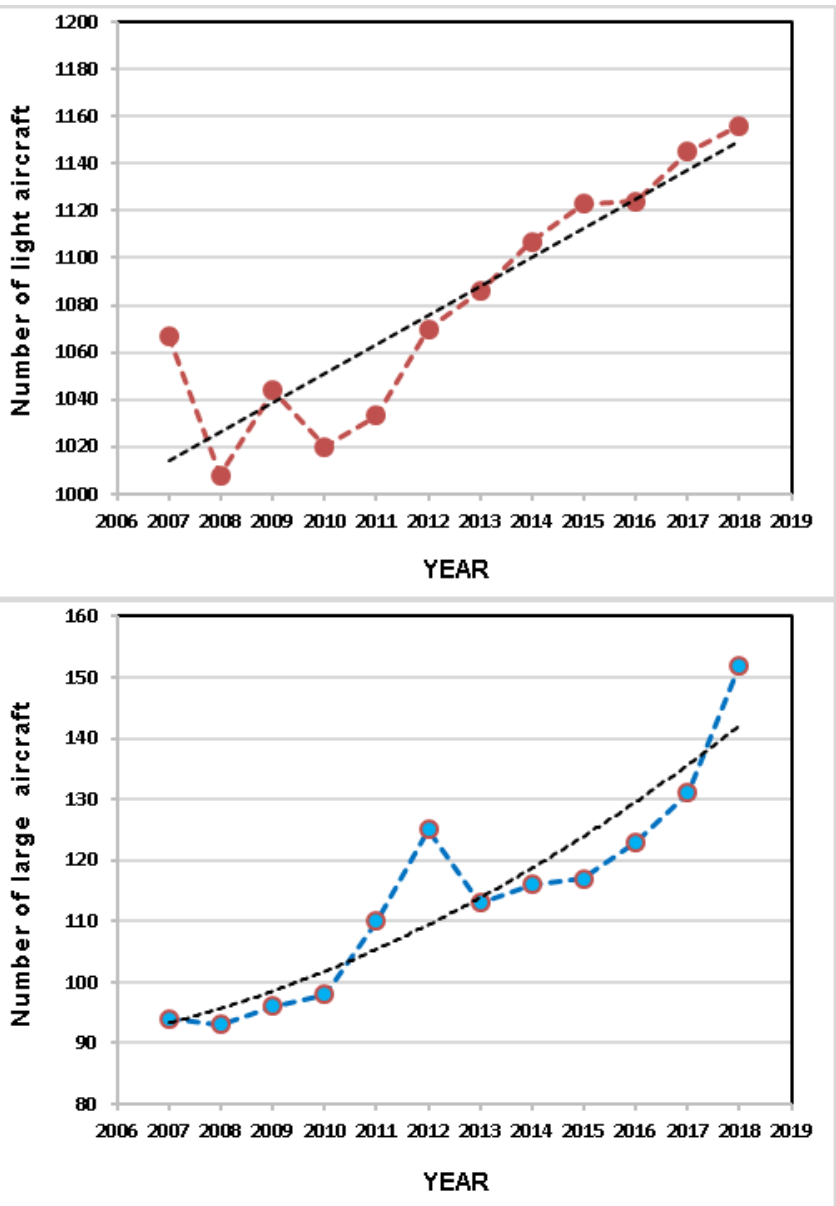

Fig. 1. Change in the number of aircraft registered in Poland

\subsection{Effects of collision energy discharge}

Previous observations of damage to the fan blades and the blades of the first compressor stages indicate that their collisions with so-called foreign bodies are found most often on 1/4-1/3 of the length of blades - measured from the tips of the shoulder blades.

When the engine is running at the take-off range, the peripheral speeds of the compressor blades at collision points reach $250-300 \mathrm{~m} / \mathrm{s}$ and the fan blades to even $400 \mathrm{~m} / \mathrm{s}$. The energy of colliding with the body of a small bird is said to be similar to the energy of a bullet from a pistol fired (see Tab. 2).

Tab. 2. The energy of a bird hitting an aircraft compares with the weapon bullet energy

\begin{tabular}{|l|c|c|c|c|}
\hline & $\begin{array}{c}\text { Type of } \\
\text { bullet }\end{array}$ & $\begin{array}{c}\text { Mass of } \\
\text { bullet }\end{array}$ & $\begin{array}{c}\text { Bullet } \\
\text { initial } \\
\text { velocity }\end{array}$ & $\begin{array}{c}\text { Energy of } \\
\text { bullet }\end{array}$ \\
\hline Gun P-64 'CZAK' & Bird & Bird & Bird & Bird \\
\hline $\begin{array}{l}\text { Small airplane } \\
\text { speed } 200 \mathrm{~km} / \mathrm{h}\end{array}$ & Starling & $80.1 \mathrm{~g}$ & $310 \mathrm{~m} / \mathrm{s}$ & $293 \mathrm{~J}$ \\
\hline $\begin{array}{l}\text { Automatic rifle } \\
\text { AK-47 'Kalash- } \\
\text { nikov' }\end{array}$ & $\begin{array}{c}\text { Intermedi- } \\
\text { ate rifle } \\
\text { cartridge } \\
7.62 \mathrm{~mm}\end{array}$ & $7.91 \mathrm{~g}$ & $715 \mathrm{~m} / \mathrm{s}$ & $2,022 \mathrm{~J}$ \\
\hline $\begin{array}{l}\text { Large aircraft } \\
\text { speed 400 km/h }\end{array}$ & Seagull & $500 \mathrm{~g}$ & $111 \mathrm{~m} / \mathrm{s}$ & $3,080 \mathrm{~J}$ \\
\hline $\begin{array}{l}\text { High-calibre } \\
\text { WKM M1921 }\end{array}$ & $\begin{array}{c}0.50 \text { BMG } \\
(12.7 \mathrm{~mm})\end{array}$ & $33-47 \mathrm{~g}$ & $\begin{array}{r}885- \\
1036 \mathrm{~m} / \mathrm{s}\end{array}$ & $18,000 \mathrm{~J}$ \\
\hline $\begin{array}{l}\text { Large aircraft } \\
\text { speed 400 km/h }\end{array}$ & Goose & $2,000 \mathrm{~g}$ & $111 \mathrm{~m} / \mathrm{s}$ & $12,320 \mathrm{~J}$ \\
\hline
\end{tabular}

The effects of 'discharging' such energy can be surprisingly serious, e.g. a swallow $(40 \mathrm{~g})$ can penetrate the cabin cover of a small flying plane and injure the pilot.

The range of damage to the turbine engine depends on the weight of the 'foreign body', flight speed and the range of engine operation (rotation speed). Most often it was found after suctioning as follows:

- a small bird (swallow, starling): disturbance of the flow through the compressor, unstable compressor operation, engine stalling;

- larger bird (seagull, crow, goose): breakage of the fan blades or first stages of the compressor rotor, damage to the air intake, damage to the wing edge, control system, puncture of the pilot cabin fairing.

Unfortunately, as much as $50 \%$ of collisions involve seagulls (Dolbeer, 2006; Wildlife Strikes, 2019). In the statistics of military aircraft accidents, the Turkish vulture (body weight $>6 \mathrm{~kg}$ ), which in the 1990s participated in about 200 collisions, with losses of over 30 million dollars, also occupies a high position.

\section{RESULTS OF DATA ANALYSYS}

\subsection{Light aircraft - with $M T O M<5,700 \mathrm{~kg}$}

Fig. 2 shows the percentage share of bird collisions for aircraft with $\mathrm{MTOM}<5,700 \mathrm{~kg}$ compared to other categories of operational air events. Fig. 3 shows the change in the number of collisions of light aircraft with birds in 2008-2018, and Fig. 4 the change in the $\mathrm{K}_{1,000}$ coefficient for this category of aircraft.

There is a systematic increase in this coefficient from 2013, but its values are small. In 2018 it came close to the alert level. Despite the fact that light airplanes very often perform air operations at field (grass) airports, collisions with birds do not dominate in the total number of reported occurrences (unlike large aircraft, for which bird strike is one of the significant causes of collision). 


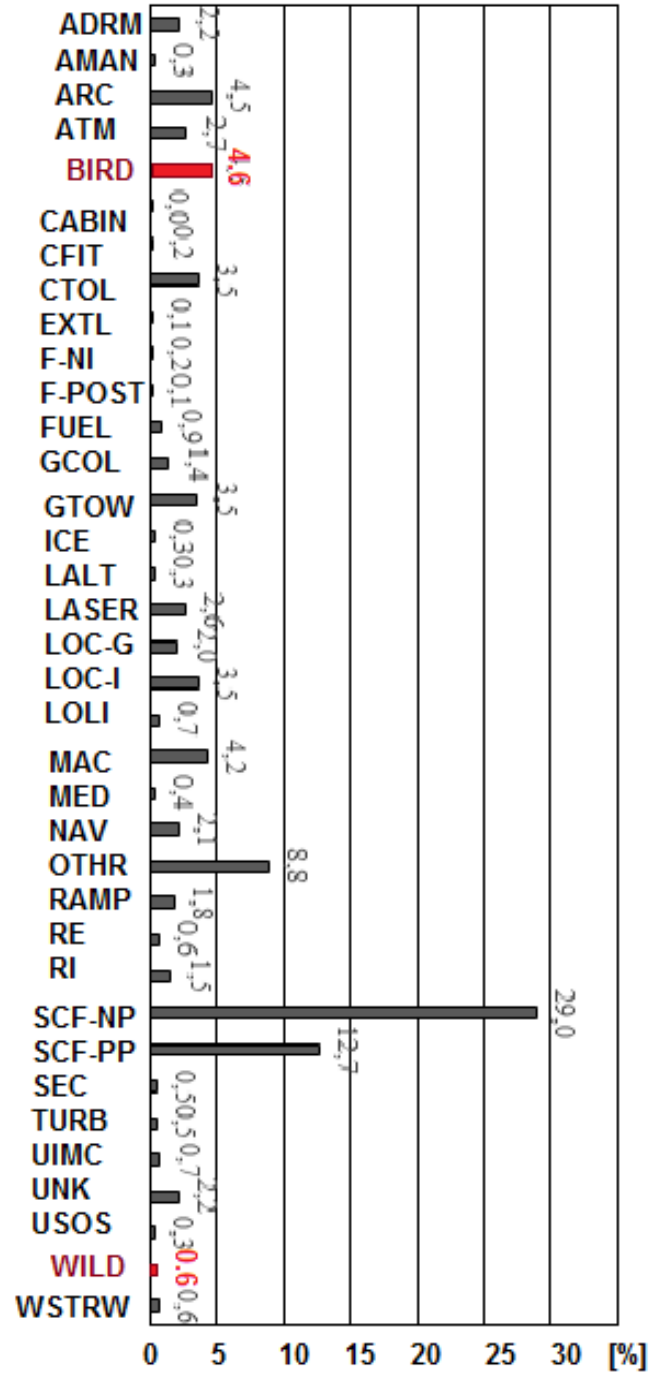

Fig. 2. Percentage share of particular categories of operational aviation events for light aircraft with MTOM $<5,700 \mathrm{~kg}$ in 2008-2018

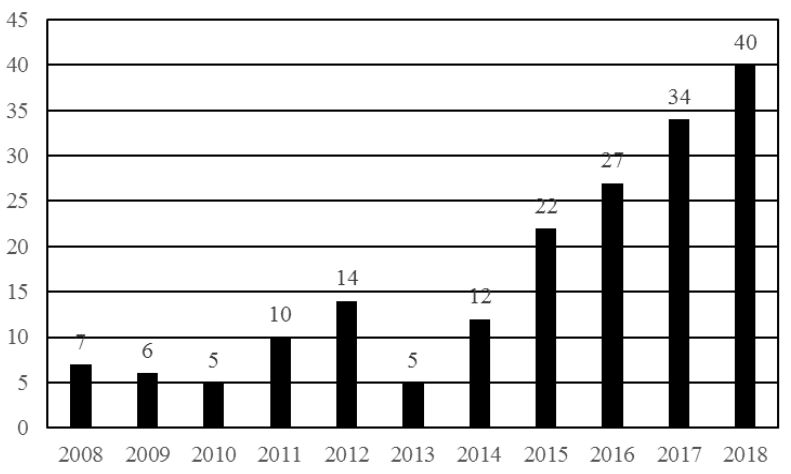

Fig. 3. Number of collisions with birds for light aircraft in the 2008-2018

Tab. 3. Probabilities of a safety hazard

\begin{tabular}{|c|c|c|}
\hline Probability & Description & Size \\
\hline Frequent & $\begin{array}{c}\text { Occurs many times (took } \\
\text { place frequently) }\end{array}$ & $\mathbf{5}$ \\
\hline
\end{tabular}

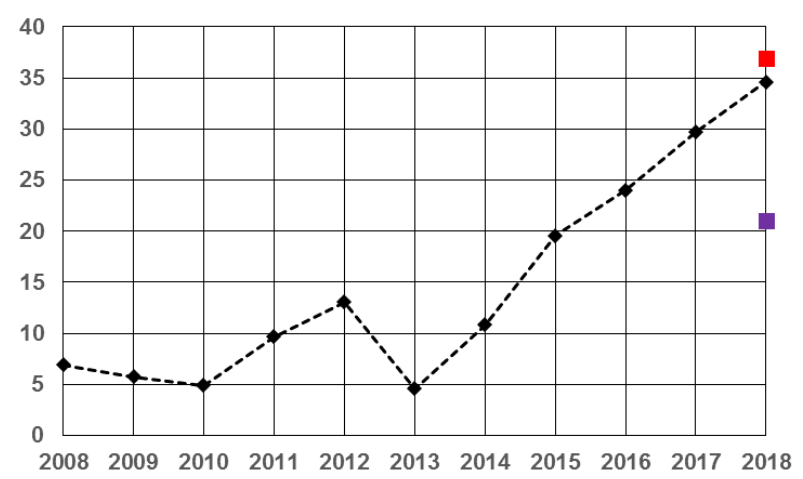

Fig. 4. Change in the $K_{1,000}$ coefficient for light aircraft in the 2008-2018

As shown in Fig. 5, the most frequent collisions with birds occur during the approach, cruising and take-off.

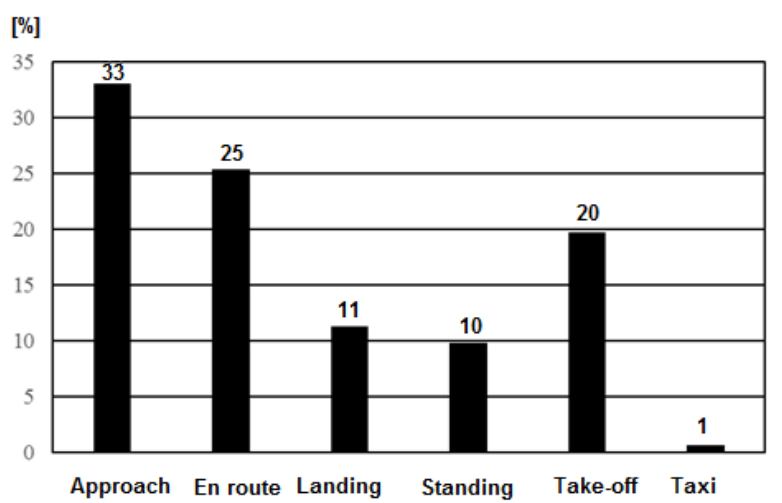

Fig. 5. Percentage of individual light aircraft traffic phases during which collisions with birds were recorded

Tab. 4. Severity assessment, safety risk in the event of collisions with birds

\begin{tabular}{|c|c|c|}
\hline Severity & Description & Level \\
\hline Lesser & $\begin{array}{c}\text { Inconvenience } \\
\text { Operational limitation } \\
\text { Using emergency procedures } \\
\text { Minor incident }\end{array}$ & D \\
\hline
\end{tabular}

Tab. 5. The real degree of threat to flight safety

\begin{tabular}{|c|c|c|c|c|c|}
\hline \multirow[b]{2}{*}{$\begin{array}{l}\text { Probability of } \\
\text { danger }\end{array}$} & \multicolumn{5}{|c|}{ Degree of danger } \\
\hline & 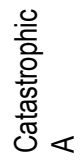 & 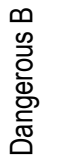 & $\begin{array}{l}0 \\
\text { 옹 } \\
\text { 을 } \\
\text { c }\end{array}$ & 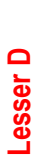 & 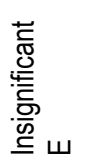 \\
\hline Unlikely & $\begin{array}{l}3 \\
\mathrm{~A}\end{array}$ & $3 B$ & $3 C$ & 3D & $3 \mathrm{E}$ \\
\hline
\end{tabular}

An important task is to determine the alert levels as well as the level of security threat resulting from bird strikes. To determine the alert levels, the methodology developed at the Institute of Aviation (Balicki at all 2016) was used. The projected average value determined in 2017 for 2018 in the drawings (Fig. 4) is marked in magenta. However, the forecasted alarm level is marked in red. The security risk was determined using the meth- 
od described in Safety Management Manual (Applying an SMS 2015, Bird Control 1991, Airport Service 2012). It should be emphasised that in Poland there were no major incidents related to the collision of aircraft with birds. That is why it was accepted that the security risk in this case is not significant. The analysis of the safety risk assessment consists in examining available statistical data and determining the level of collision effects with birds. In this case, it becomes necessary to rely on facts and not consider the potential possible effects of such events. Otherwise, it would lead to a situation in which virtually most aviation events could be classified as severe: level A - i.e. catastrophic. It was assumed on the basis of statistical data that for airplanes with MTOM $<5,700 \mathrm{~kg}$, the security risk has a lower severity, as shown in Tab. 4. However, Tab. 3 presents the assessment of the likelihood of a security risk as isolated (unlikely). From conclusions drawn fromanalysing Tabs 3 and 4, a safety risk assessment matrix is constructed, which is presented in Tab. 5. It shows that for light airplanes, the real degree of threat to flight safety caused by collisions with birds is very low.

\subsection{Large aircraft - with MTOM $>5,700 \mathrm{~kg}$}

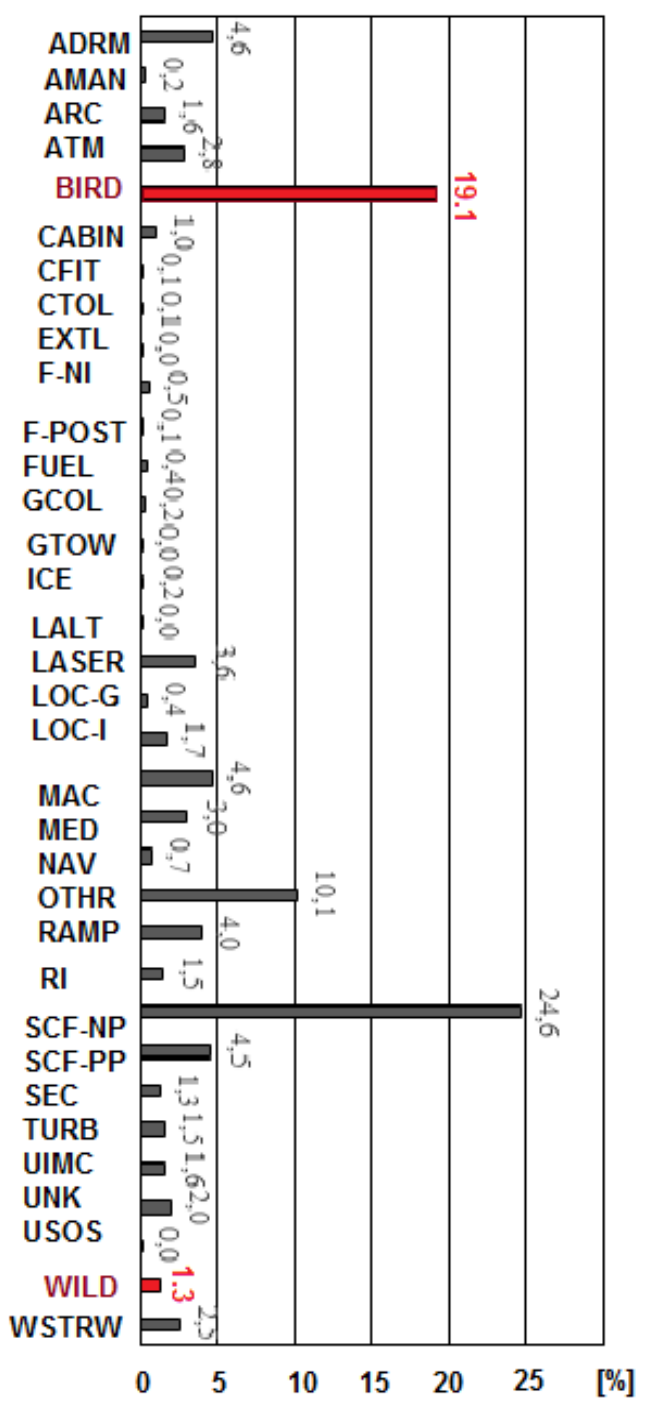

Fig. 6. Percentage share of individual categories of operational aviation events for large aircraft with MTOM > 5,700 kg in 2008-2018
The turbine engines of large aircraft are particularly sensitive to collisions with birds. The Bird Strike Committee Europe recommends, for example, the following:

- Plan the flight route in such a way as to avoid bird flyways;

- Avoid low-altitude flights, especially along sea shores, rivers, cliffs (these are nesting sites), lakes, islands, processing plants (especially fish) and landfills;

- Practice the procedures to be followed in case of damage to the cabin cover, engine damage;

- During landing, after noticing the flock of birds on the final approach to the lane, it is better to stop the landing and go to the second approach (unsuccessful approach procedure);

- After a collision with a bird, if possible, a control test should be carried out before the approach, and if the bird has been sucked into the engine, a flight procedure with a failed engine should be performed.

After a systematic decrease in the number of collisions with birds in the period 2009-2013 in the past 5 years, there was a clear increase. In 2018, despite a much larger number of bird strikes compared to those in 2017 , the $\mathrm{K}_{1,000}$ ratio dropped due to the fact that the number of registered aircraft had increased. This ratio is between the projected average value and the alert level. The number of aviation events related to bird strikes in the years 2008-2018 is shown in Fig. 7, and in Fig. 8 is shown the values of the $\mathrm{K}_{1,000}$ coefficient. It is important to emphasise the fact that, according to the ICAO document, every bird-related event should be recorded, not only those confirmed by traces of impact on the airframe or power unit, but also those that could lead to a collision.

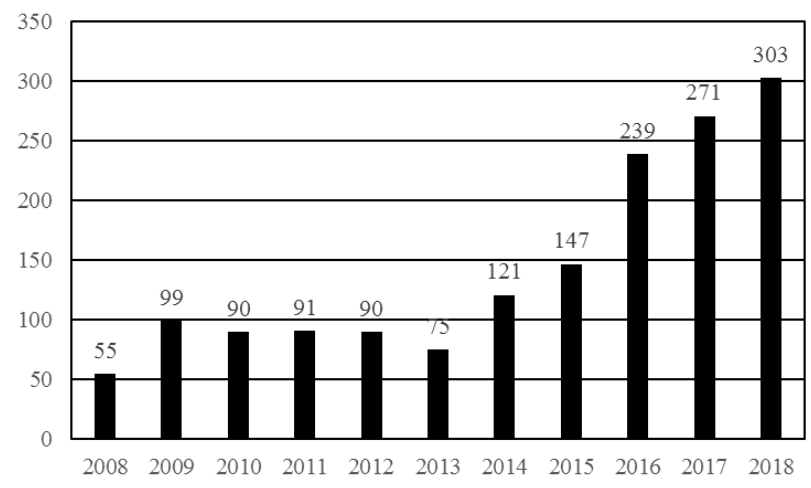

Fig. 7. Increase in the number of collisions with birds for aircraft with MTOM > 5,700 kg between 2008 and 2018

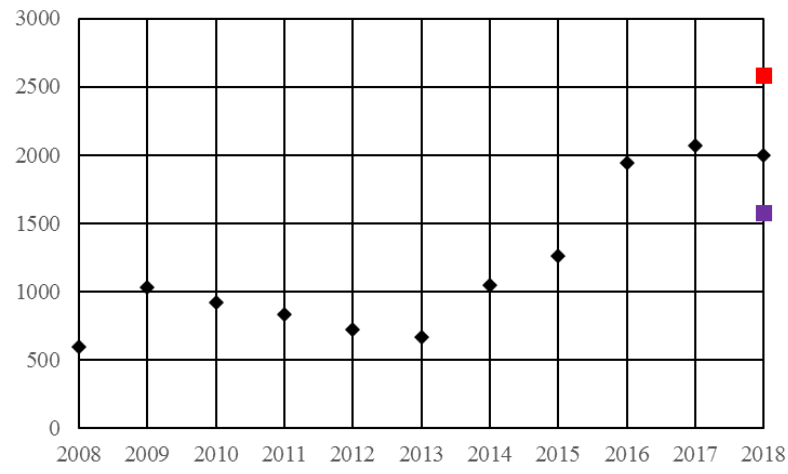

Fig. 8. K1,000 values for large aircraft collisions with birds in 2008-2018 


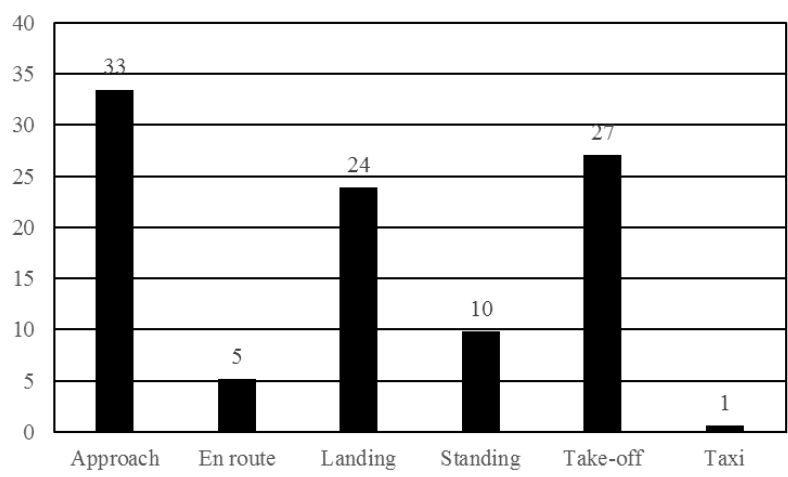

Fig. 9. Percentage of individual large aircraft traffic phases during which collisions with birds were recorded

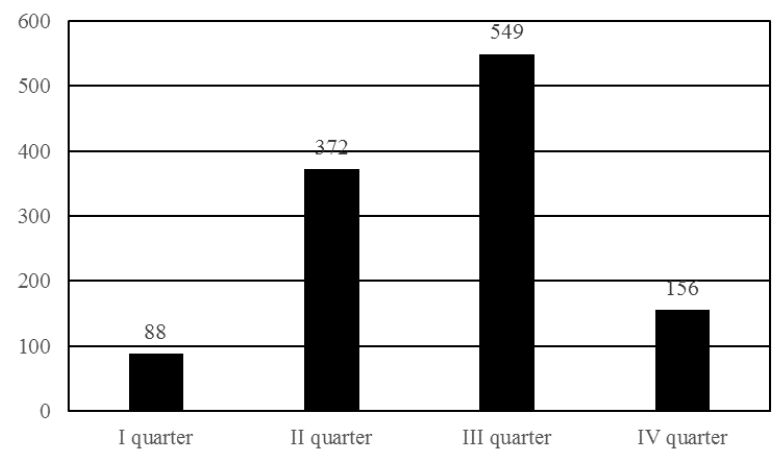

Fig. 10. Number of occurrences with birds near airports in individual quarters for aircraft with MTOM > 5,700 in 2011-2018

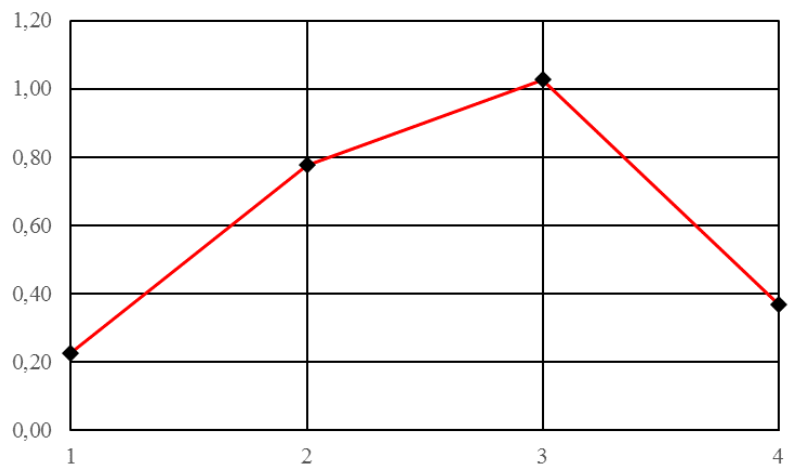

Fig. 11. Values of the number of bird events reported in relation to the number of passenger operations of large aircraft in individual quarters of the year

Fig. 9 shows the percentages of individual phases of flight during which bird strikes were reported. They occur most often during the approach, take-off and landing of the aircraft. It is somewhat obvious because of the limited 'flight altitude range' of birds. Almost every tenth event involving birds is detected only during aircraft inspection.

The above results are attributable to the fact that a significant number of bird collisions are not perceived by the crew and therefore are not reported by the pilots, but are only detected by the maintenance services.

Figs. 10 and 11 show the seasonality of changes of collision factor with birds in the number of passenger operations in 20112018. Most of them occur in the third quarter of the year, and the least in the winter.
Similar to the assessment carried out for light aircraft, the safety risk assessment matrix presented in Tab. 8 was developed. Likewise, for light aircraft, the consequences of collisions with birds of large aircraft were of lesser severity (Tab. 7), whereas the probability of this event is frequent (Tab. 6).

Tab. 6. Probabilities of a safety hazard

\begin{tabular}{|c|c|c|}
\hline Probability & Description & Size \\
\hline Frequent & $\begin{array}{c}\text { Occurs many times (took place } \\
\text { frequently) }\end{array}$ & 5 \\
\hline
\end{tabular}

Tab. 7. Severity assessment, safety risk in the event of collisions with birds

\begin{tabular}{|c|c|c|}
\hline Severity & Description & Level \\
\hline Lesser & $\begin{array}{c}\text { Inconvenience } \\
\text { Operational limitation } \\
\text { Using emergency procedures } \\
\text { Minor incident }\end{array}$ & D \\
\hline
\end{tabular}

Tab. 8. Real safety risk of performing flights

\begin{tabular}{|c|c|c|c|c|c|}
\hline \multirow[b]{2}{*}{$\begin{array}{l}\text { Probability of } \\
\text { danger }\end{array}$} & \multicolumn{5}{|c|}{ Degree of danger } \\
\hline & 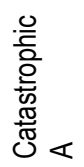 & 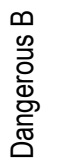 & $\begin{array}{l}0 \\
\text { ? } \\
\text { 은 } \\
\stackrel{\infty}{\infty}\end{array}$ & 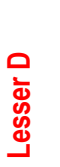 & 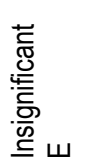 \\
\hline Frequent & $\begin{array}{l}5 \\
\mathrm{~A}\end{array}$ & $5 B$ & $5 \mathrm{C}$ & 5D & $5 \mathrm{E}$ \\
\hline
\end{tabular}

Although the analysis presented shows that the degree of risk is not high, the causes of the systematic increase in aviation events caused by bird strikes should be controlled and appropriate measures taken to reduce the possibility of a serious accident.

\section{ACTIONS TO REDUCE THE RISK ASSOCIATED WITH BIRD STRIKES}

\subsection{Tests of engine resistance to bird collisions}

During the implementation of the PZL-I22 'Iryda' aircraft programme, the Institute of Aviation conducted tests of turbine engines' resistance to collisions with birds. This type of research was carried out for the first time in our country, on a specially constructed test stand equipped with a pneumatic launcher and measuring apparatus (see Fig. 12) (Balicki at al., 2016). The pneumatic launcher with a 75-m barrel was supplied with compressed air (maximum pressure $0.8 \mathrm{MPa}$ ). The hydraulic retarding device controlled the increase in air pressure, and thus the container with a 'foreign body' (lumps of ice or a bird weighing up to $2 \mathrm{~kg}$ ) was accelerated with an acceleration of not more than $50 \mathrm{~g}$ (g - gravitational acceleration; exceeding $50 \mathrm{~g}$ could crush the bird - that is the reason for the barrel length). The trigger unit has been activated by an electric signal from the operator's cab. At the same time, a fast film camera and an electronic container speed measuring system at the exit of the barrel were launched. 
1

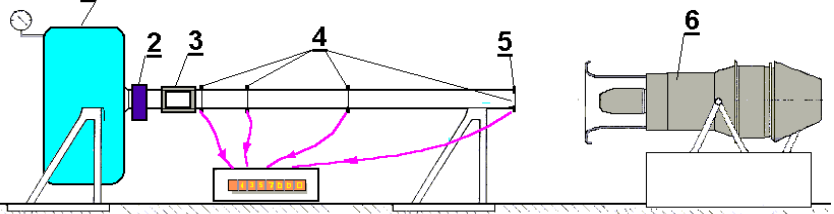

Fig. 12. Schematic diagram of a stand with a pneumatic launcher $f$ or testing engine resistance to foreign body impact: (1 - compressed air tank, 2 - electric trigger with hydraulic delay unit, 3 - container with a 'foreign body', 4 - container speed measuring system, 5 - barrel outlet with a container stop device, 6 - engine tested)

The obtained tank movement speeds depended on the initial air pressure in the tank:

- for a pressure of $0.2 \mathrm{MPa}$ the speed was $160 \mathrm{~m} / \mathrm{s}$;

- for $0.8 \mathrm{MPa}$, the speed was $250 \mathrm{~m} / \mathrm{s}$.

According to the regulations, after a collision with a bird shot at $200 \mathrm{~m} / \mathrm{s}$ into the engine inlet operating in the take-off range, damage to the units may prevent its further operation, but no part of the engine can get out of its nacelle, threatening the airframe structure and its installations.

\subsection{Increasing crash resistance by changing engine and airframe design}

Experience till date shows that every single-flow engine is destroyed during take-off after a collision with a large animal (over $0.5 \mathrm{~kg}$ ). This is because the impacted blades of the first stage of the compressor bend and 'rub' against the stationary steering blades behind them. The rotor performs $100-200$ rotations per second. The chances of reducing the size and area of damage should be seen in the fragmentation of the bird's body before impacting the rotating vanes. For this purpose, for example, ribs acting as knives were placed in the inlets of a PZL TS11 aircraft. A similar effect can be achieved by properly shaping (bending) the inlets to the jet engines of combat aircraft so that the birds bumping against the duct walls (at a speed of about $200 \mathrm{~m} / \mathrm{s}$ ) reach the rotors already sufficiently smashed. The use of this method requires appropriate computational and experimental research for each newly designed aircraft. One of the effects of such research is the design of a new, jet engine by General Electric (Dolbeer R.A. 2006), presented in Fig. 13 (GEnx series).

Based on the analysis of the 'foreign object' motion paths, in the inlet and flow ducts of this engine, the shape of the cap (conical-elliptical) was developed so that the falling elements (dust grains, pieces of ice, birds) would be ejected into the external flow duct of the engine, i.e. they would bypass the inlet to the low-pressure compressor. This is also done by increasing the distance between the fan rotor and the compressor inlet. As a result, grains with diameter $>0.25 \mathrm{~mm}$ are ejected into the outer channel.

The fan blades of the GEnx series engines are made of carbon fibre composites. In the event of breakage, the blade is kept inside the engine nacelle (it does not pierce the nacelle wall), thanks to special reinforcements (bandage - armor) and 'pockets' into which it retracts after detaching from the hub.

When the engine is running in the low thrust range, e.g. when taxiing the plane to the runway, the discharge valves from the low pressure compressor open (inwards). This enables the ejection of finer particles from the compressor into the engine outer duct.

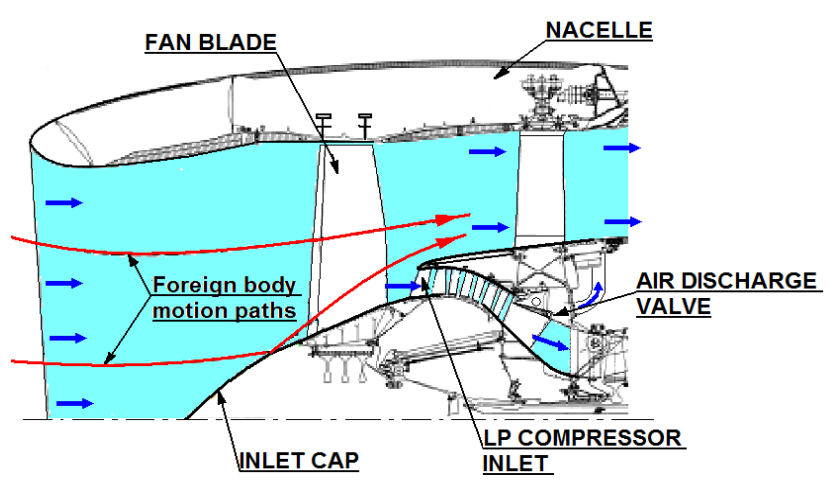

Fig. 13. A method of shaping the inlet of a large jet engine to increase resistance to damage caused by the ingress of a 'foreign body'

\subsection{Crash prevention}

The development of civilisation often creates conflicts concerning the coexistence of man and nature. Unfortunately, this also applies to the development of air traffic. 'For the safety of both parties', birds should be discouraged from being around airports. This is done by depriving the area of all the elements attractive for them, i.e. liquidation of feeding grounds near airports, drying water reservoirs, removing landfills - sources of food, mowing grass and thus depriving birds of comfortable shelters at the airport (Birdstrike risk, 2007; Shamoun-Baranes, 2008; Summary of Wildlife Strikes, 2017).

Birds repelling is another range of protective measures. For this purpose, the following areused:

- pyrotechnics: firecrackers, automatic gas cannon, firearms;

- acoustic means: e.g. 'shout of fear' reproduced around loudspeakers, or voices of hunting predators (high recording quality must be maintained);

- chemicals: spraying repellents, e.g. anthranilic methylate (range up to $500 \mathrm{~m}$ );

- use of trained birds of prey and trained dogs (the most effective border collie, which, however, must be accustomed to airplanes, and denied from entering the runway);

- a motorised 'flying crew' to drive away the flock.

The main disadvantage of all these deterrents is that the birds get used to them and therefore the same method cannot be used for a long time.

Flock detection systems in the vicinity of airports (usually passive infrared sensors) and information on bird migration/flights (satellite telemetry) are used to reduce the likelihood of aircraft encounters with birds. One of the ideas of such a system, presented in Fig. 14, was created during the observation of the spread of the H5N1 bird flu virus and assumes the use of the existing meteorological and military radar network to observe bird behaviour 'in real time'.

This network includes the following:

- long-range military surveillance radars - observation of migration of large flocks of birds within $150 \mathrm{~km}$;

- weather radars - images of bird flights according to flight altitude within $25 \mathrm{~km}$;

- specialised short-range radars $(5-10 \mathrm{~km})$ - movements near airports and training grounds. 
2. Balicki W., Głowacki P., Loroch L (2016), Safety performance indicators assessment for small aircraft airframe systems, Journal of KONES Powertrain and Transport, 23(2), 31-38.

3. Bird Control and Reduction, Airport Services Manual, (1991) Third Edition, Doc 9137 - AN/898, Part 3 Montreal, Canada,

4. Bird strike, a European risk with local specificities, (2013), European General Aviation Safety Team, Edition 1 - Germany,

5. Birdstrike risk/Warning procedures, (2007) STANAG 3879 FS (Edition 7), Military Committee Standardization Board (MCASB), NATO Standardization Agency

6. Cleary E.C., Dolbeer R. A. (2005), Wildlife hazard management at airports, a manual for airport operators, Second edition, Federal Aviation Administration, Office of Airport Safety and Standards, Washington, D.C. USA,

7. Convention on International Civil Aviation, Chicago 1944, doc 7300/9, Ninth Edition, available at: www.icao.int

Fig. 14. Concept for a bird migration monitoring system to increase flight safety (Shamoun-Baranes, 2008)

Attempts have already been made to implement such a system to protect NATO air bases in Belgium, with a view to extending it to the Netherlands, France and Germany. Information on the likelihood of encounters of flying birds in the different zones of the observed area and current bird activity near the departure and destination airports is included in the bulletins (e.g. BIRDTAM - Bird Notice To Air Man) and should be taken into account in route planning.

\section{CONCLUSION}

The analysis of events included in the ECCAIRS database allows us to conclude that in Poland the actual level of risk of a dangerous event involving birds and large aircraft is moderate. However, air surveillance and airport authorities should take action to reduce the number of collisions with birds. Their number has been constantly increasing since 2013 - since then the probability of such an event has increased by four times.

Due to the increasing risk of collisions, there is a need for behavioural studies of birds in the vicinity of airports. Climate change, food distribution sites and low risk from predators contribute to their presence. They are also likely to become accustomed to the ways that are being used to deter them.

Every tenth collision with a bird is not noticed by the crew and its effects are only detected during technical inspections of aircraft.

What is puzzling is the small number of incidents reported for light aircraft (MTOM $<5,700 \mathrm{~kg}$ ), although they operate mostly at airports and in remote areas. According to the current legal regulations, the level of self-service of small aircraft is expanding. In the current system, reporting of bird crashes should not be expected to increase due to the fact that the level of risk is accepted by small aircraft owners. It therefore seems appropriate to review the standards that cover bird collisions and related requirements. The results of analyses and examples of incidents related to bird collisions should also be disseminated in the industry and in specialised publications.

\section{REFERENCES}

1. Applying an SMS Approach to Wildlife Hazard Management, (2015) Airport Cooperative Research Program Report 145, National Academy of Sciences. Transportation Research Board, Washington D.C.

8. Dale L.A. (2009), Personal and corporate liability in the aftermath of bird strikes: a costly consideration, University of Nebraska - Lincoln, Human - Wildlife Conflicts 3(2), 216-225,

9. Directive 2003/42/EC of the European Parliament and of the Council on occurrence reporting in civil aviation, (2003) Official Journal L $167,04.07 .2003$, pp. $23-36$

10. Dolbeer R. A. (2006), Bird and Other Wildlife Hazards at Airports: Liability Issues for Airport Managers, University of Nebraska - Lincoln, Wildlife Damage Management, Internet Center for USDA National Wildlife Research Center - Staff Publications,

11. Federal Aviation Administration (1990-1999), Wildlife strikes to civil aircraft in the USA,

12. Fernandez -Juricic E., Gaffney J., Blackwell B., Baumhardt P., (2011), Bird strikes and aircraft fuselage color: a correlational study, Human-Wildlife Interactions 5(2): 224-234,

13. Fortońska A. (2018), The impact of bird strikes on air transport safety, Scientific Papers of Silesian University of Technology. Transport, vol. 98

http: //digitalcommons.unl.edu/hwi/12 http://digitalcom mons.unl.edu/icwdm usdanwrc/142

14. ICAO, (2012), Airport Service Manual. Wildlife Control and Reduction, Doc 9137P3 AN/898, Fourth Edition, ISBN 978-92-9231-9298

15. Kelly T.C., Allan J. (2006), Ecological effect of aviation, in Davenport J. and Davenport J.L. editors. The ecology of transportation: managing mobility for the environment, Springer, Dordrecht, Netherlands,

16. Korte G. (2019), Planes strike birds more than 40 times a day, FAA data show, USA TODAY

17. Matijaca A. (2001), Damage Liability and Compensation in Case of Bird Strike, Proceedings of the 3-rd Joint Bird Strike Committee USA/Canada, Calgary, 89-100, http://www.int - birdstrike.org.

18. Matijaca A., (2008), Possible Exoneration of Airport from liability for bird strike damage. Proceedings of the 28-th International Bird Strike Committee, Brasil, 1-16, ://www.int - birdstrike.

19. Regulation (EC) No 261/2004 of the European Parliament and of the Council of 11 February (2004) establishing common rules on compensation and assistance to passengers in the event of denied boarding and of cancellation or extended delay of flights, and repealing, Regulation (EEC).Official Journal No 295/91, No 46, p. 1.

20. Reza H., Mojtaba S.(2015), Bird Strike, an Experimental, Theoretical and Numerical Investigation, Woodhead Publishing in Mechanical Engineering, Elsevier Ltd.

21. Shamoun-Baranes J. (2008), The Bird Migration System of Systems FlySafe and Beyond, IAP information day, Brussels,

22. Summary of Wildlife Strikes Reported to the ICAO Bird Strike Information System (IBIS) for the years 2008 - 2015, ICAO EB 2017/25, 12 May 2017.

23. Wildlife Strikes to Civil Aircraft in the United States 1990s2017, FAA Washington, DC. January 2019 